\title{
Wybrane aspekty techniczno-organizacyjne budowy i eksploatacji laboratoryjnych, spawalniczych stanowisk zrobotyzowanych
}

\author{
Some aspects of technological and structural configuration \\ and exploitation of laboratory welding robot setups
}

\section{Streszczenie}

Robot przemysłowy zainstalowany w uczelnianym laboratorium może być zarówno obiektem badań, jak i doskonałym narzędziem, zapewniającym trudną do osiągnięcia innymi środkami wszechstronność, elastyczność oraz precyzję działania. W obydwu przypadkach wymaga odpowiedniego wyposażenia i osprzętu technologicznego, a także procedur, instrukcji i zabezpieczeń. W artykule omówiono wybrane aspekty konfiguracji i zabezpieczeń robotów spawalniczych wykorzystywanych w warunkach laboratoryjnych w Zakładzie Inżynierii Spajania Politechniki Warszawskiej.

Słowa kluczowe: robot spawalniczy; spawanie; konfiguracja; zabezpieczenia

\section{Abstract}

An industrial robot being installed in university laboratory might be an object of tests itself as well as good tool assuring high precision operation, universality and flexibility, difficult to obtain with other facilities. In both cases some auxiliary equipment such as manufacturing accessories as well as procedures, manuals and safety arrangements is necessary. Same aspects of structural configuration and safety arrangements being used in laboratory of Welding Engineering Division of Warsaw University of Technology are described in this paper.

Keywords: industrial robot; welding; robot configuration; safety arrangements

\section{Wprowadzenie}

Zakład Inżynierii Spajania Politechniki Warszawskiej od chwili swojego powołania w roku 1951 (jako Katedra Spawalnictwa) wiele uwagi poświęcał zagadnieniom mechanizacji, a następnie automatyzacji i robotyzacji. Początkowo bazę laboratoryjną stanowiły pozycjonery, obrotniki i traktory spawalnicze...

W roku 1991 pojawił się pierwszy robot - licencyjny IRp-6 z ZAP-Robotyka z Ostrowa Wielkopolskiego, oparty na konstrukcji pierwszego na świecie uniwersalnego robota przemysłowego z napędem elektrycznym i sterowaniem mikroprocesorowym (ASEA IRB, 1975-1992). Jego pięcioosiowy manipulator antropomorficzny (wszystkie osie obrotowe) o sześciokilogramowej nośności pozwala na programowanie ruchów interpolowanych liniowo i kołowo z dobrą powtarzalnością pozycjonowania +/-0,2 mm. W trakcie wieloletniej eksploatacji pojawiły się liczne modernizacje, rezolwery zastąpiono enkoderami w układach sprzężenia zwrotnego silników napędowych oraz całkowicie wymieniono jednostkę centralną układu sterowania. Zastosowano m.in. 32-bitowy procesor Motorolii system operacyjny czasu rzeczywistego OS-9. Zwiększyła się dynamika i płynność ruchu ramienia robota [11].
Pomimo modernizacji, liczne ograniczenia sprzętowe robota IRp-6 (brak szóstej osi, mały zakres ruchu) i programowe (prosty, zamknięty język programowania) sprawiały, że w niewystarczającym zakresie wspomagał zaawansowane badania laboratoryjne, przede wszystkim pełniąc rolę precyzyjnego i wytrwałego operatora podczas spawania, napawania czy w innych pracach, np. wielogodzinnych próbach zmęczenia cieplnego (rys. 1a). Z drugiej strony, jego ograniczenia stawały się zaletami podczas niektórych zajęć edukacyjnych - łatwy do szybkiego opanowania język programowania, zawierający jednak wszystkie kluczowe elementy programu roboczego, a ograniczony zakres ruchów i prędkość gwarantowały bezpieczeństwo podczas nauki, testów i pokazów (rys. 1b). Niestety, zużycie podzespołów elektronicznych oraz samego manipulatora spowodowało ogólne obniżenie parametrów pracy, pojawiło się nadmierne przeregulowanie i oscylacje niektórych osi [3].

Obecnie, laboratorium wyposażone zostało w dwie nowe jednostki o różnych strukturach kinematycznych i przeznaczeniu, wymagających odmiennego wyposażenia i osprzętu technologicznego, a także procedur obsługi i zabezpieczeń. Omówiono je w dalszej części.

Dr inż. Paweł Cegielski, dr inż. Mariusz Bober - Politechnika Warszawska.

Autor korespondencyjny/Corresponding author. pcegiels@wip.pw.edu.pl 

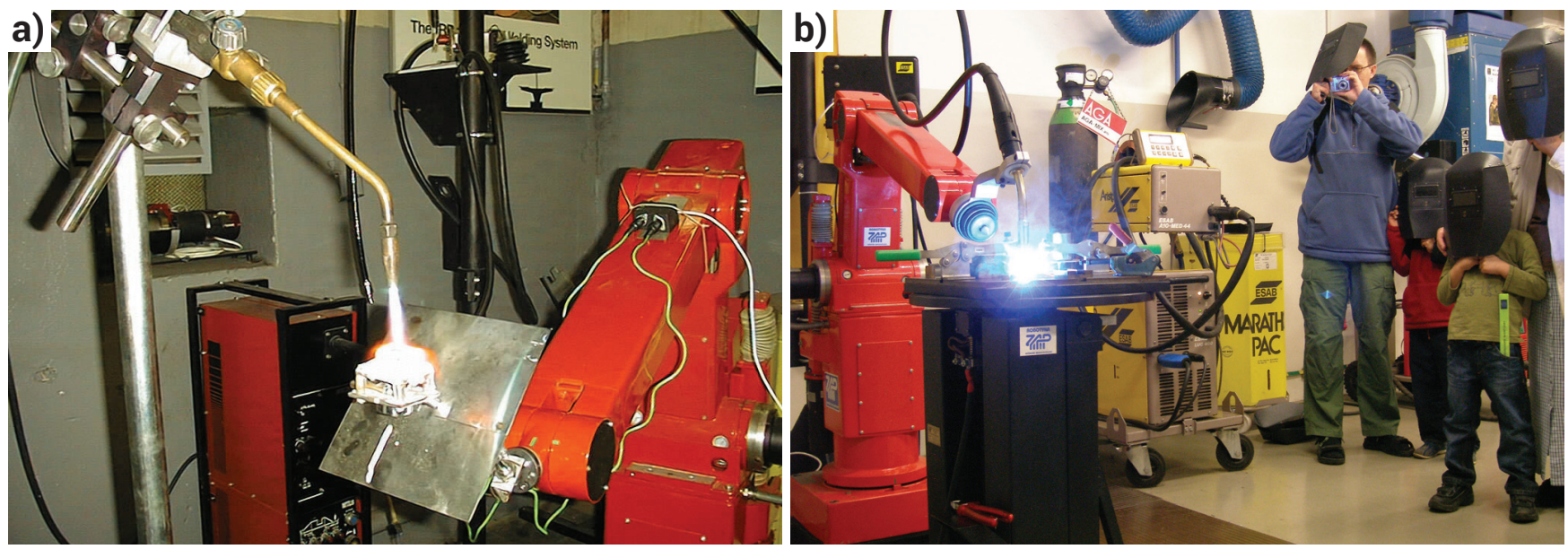

Rys. 1. Robot IRp-6 w laboratoriach Zakładu Inżynierii Spajania: a) badania zmęczenia cieplnego (rok 2002), b) podstawy programowania podczas Festiwalu Nauki (rok 2007)

Fig. 1. Robot IRp-6 installed in Welding Engineering Division laboratory: a) under thermal fatigue tests (2002), b) basis of programming during Science Festival (2007)
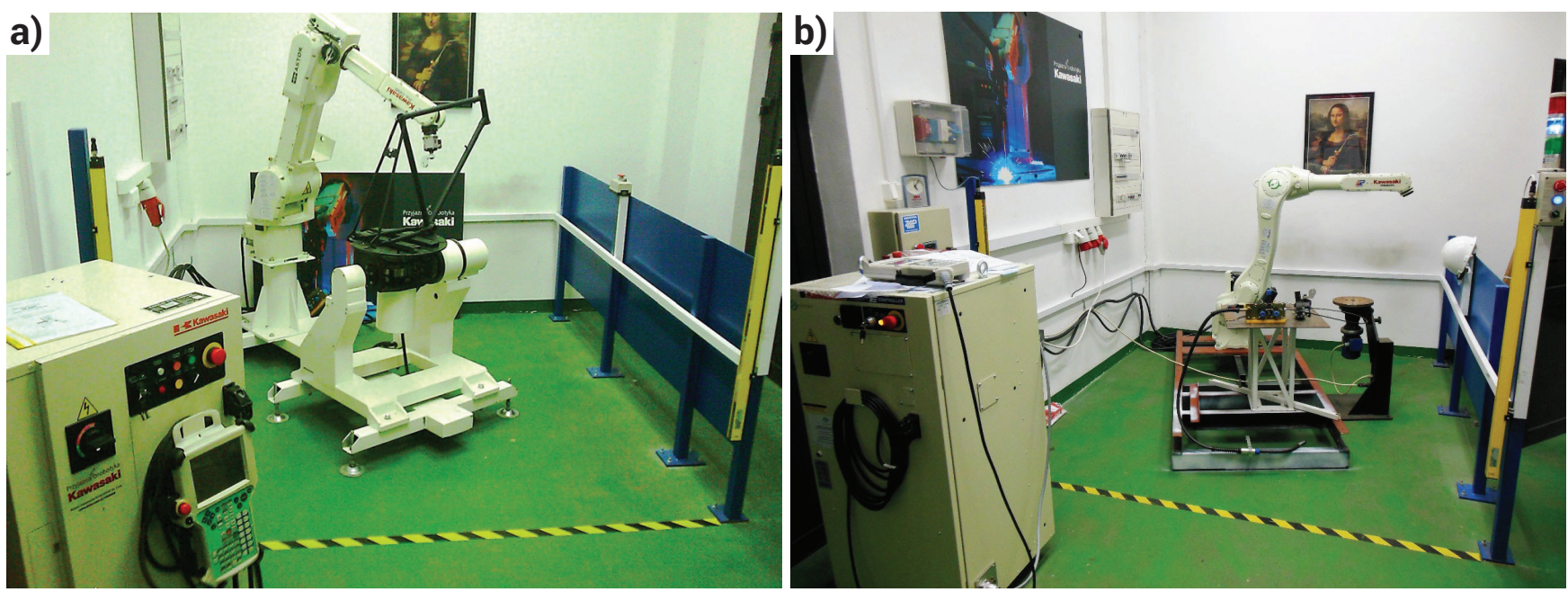

Rys. 2. Wypożyczone roboty Kawasaki: a) spawalniczy FA006E z kontrolerem D40 i zintegrowanym dwuosiowym pozycjonerem, b) uniwersalny RS20N z prostym pozycjonerem

Fig. 2. Kawasaki robots: a) welding robot FA006E with D40 controller integrated with two setups positioner, b) universal RS20N with a positioner

Należy także zaznaczyć, że na podstawie wieloletniej umowy o współpracy z firmą ASTOR w laboratorium Zakładu nieodpłatnie eksploatowano różne jednostki doskonałych robotów firmy Kawasaki (rys. 2) [4].

\section{Kryteria wyboru robota}

Do spawania łukowego i procesów pokrewnych stosowane są przede wszystkim 6-osiowe roboty przemysłowe o strukturze antropomorficznej $[2,5,9]$. Tworzą ją wyłącznie osie obrotowe, zapewniając wysokie zdolności manipulacyjne w zakresie pozycjonowania (ruchu w przestrzeni kartezjańskiej) i orientacji (pochylania) efektora (narzędzia), skuteczne omijanie przeszkód i dużą przestrzeń roboczą. Roboty o strukturze antropomorficznej dominują także w zastosowaniach przemysłowych (59\% zastosowań w zestawieniu z innymi strukturami według raportu Międzynarodowej Federacji Robotyki z roku 2011).

Pozostałe wymagania stawiane robotom antropomorficznym, istotne z punktu widzenia spawania zrobotyzowanego, to $m$.in. $[2,5]$ :

- udźwig od ok. 3 do 20 kilogramów;

- powtarzalność pozycjonowania w zakresie od ok. \pm 0,01 do $0,20 \mathrm{~mm}$;

- liczba stopni swobody od 5 (głównie starsze konstrukcje) do 7 (niektóre modele specjalne firm CLOOS czy Motoman) - typowo 6;

- możliwie jak największy zasięg ramienia (zakres przestrzeni roboczej);

- stojąca lub odwrócona pozycja pracy;

- programowanie ręczne przez nauczanie, opcjonalnie wspomagane trybem off-line;

- możliwość zdefiniowania parametrów punktu roboczego narzędzia (TCP);

- zdolność do precyzyjnego odtwarzania złożonych ścieżek z pełną kontrolą prędkości i trajektorii, np. w oparciu o funkcje interpolacji (liniowej, kołowej);

- dostępne odpowiednie interfejsy komunikacyjne.

Sześć stopni swobody manipulatora antropomorficznego gwarantuje swobodne pozycjonowanie (docieranie do różnych miejsc) i orientowania (kątowego ustawienia w przestrzeni). Pięcioosiowe, głównie starsze jednostki (np. IRp-6), posiadały pewne ograniczenie funkcjonalne w zakresie orientowania (typowo brakowało jednej osi w układzie kiści - nadgarstka robota). Uniemożliwiało to osiąganie niektórych pozycji oraz utrudniało prace interpolatorów, zwłaszcza kołowego. Oczywiście do celów edukacyjnych i badawczych najbardziej pożądana będzie jednostka o sześciu osiach. Z drugiej strony, od lat obserwuje się próby zastosowania do procesów spawalniczych innych struktur kinematycznych i mniejszej liczby osi. 
Przykładem mogą być wczesne próby firm ASEA i ESAB z aplikacją robota typu SCARA (uzupełnionego o dodatkowe osie kiści) do spawania łukowego (lata 80.). Brak kontynuacji nie oznaczał całkowitej rezygnacji z tej struktury. Nominalnie czteroosiowy robot SCARA, przeznaczony przede wszystkim do prostych prac z chwytakiem, znalazł zastosowanie w aplikacjach lutowania obwodów elektronicznych (rys. 3).
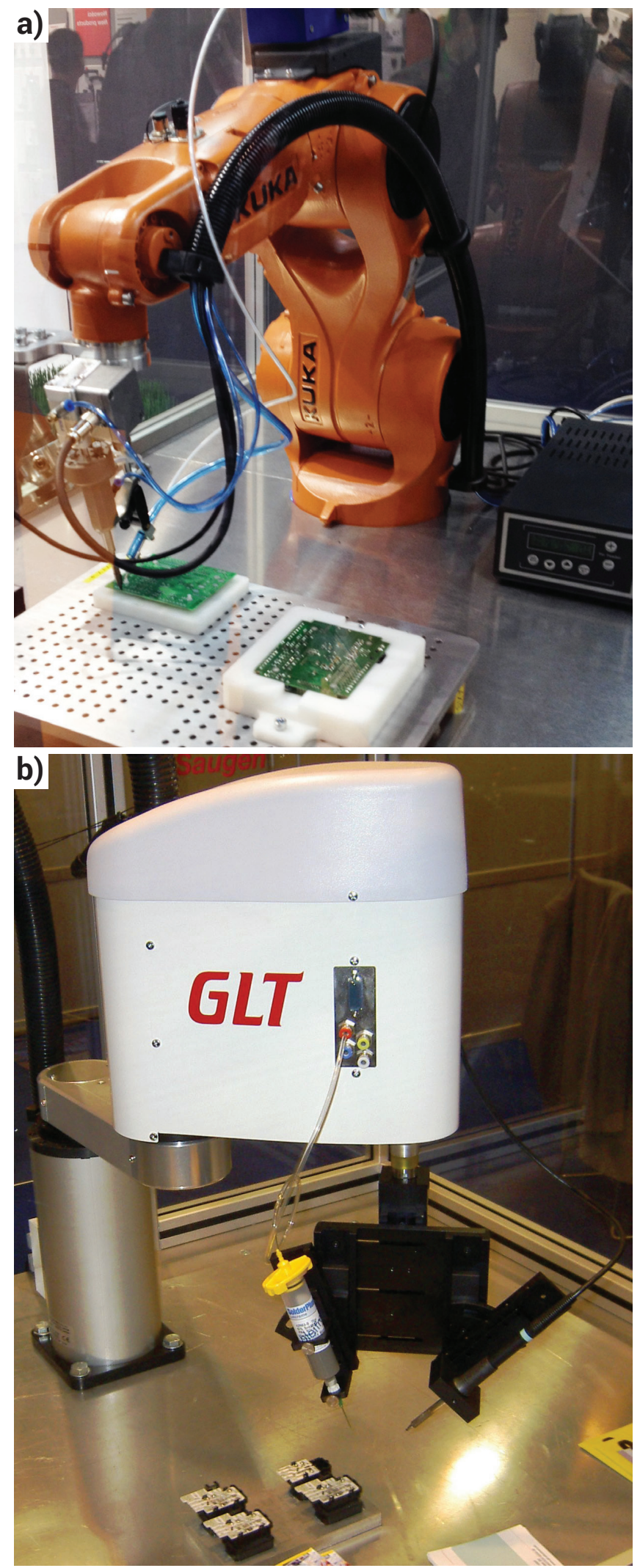

Rys. 3. Lutowanie zrobotyzowane: a) sześcioosiowym robotem antropomorficznym (KUKA), b) czteroosiowym robotem SCARA (GLT)

Fig. 3. Robotized brazing with the use of: a) 6-axis anthropomorphic robot (KUKA), b) 4-axis robot SCARA (GLT)
Struktura antropomorficzna również występuje w uproszczonej wersji czteroosiowej, przeznaczonej głównie do paletyzacji, o rozmiarach i nośności znacznie wykraczających poza potrzeby spawania łukowego i procesów pokrewnych. A jednak, po dołączeniu do kołnierza takiego robota mniejszej jednostki sześcioosiowej powstał unikalny system spawalniczy o 10 osiach, 5 kg nośności i zasięgu możliwym do osiągnięcia jedynie przy połączeniu standardowego robota z trzyosiowym systemem lokomocyjnym (ABB IRB 800). Ostatnie doświadczenia autorów, omówione w dalszej części artykułu, także rozszerzają paletę struktur robotów stosowanych od zadań spawalniczych.

Z punktu widzenia zasięgu ramienia najbardziej rozpowszechnione są roboty spawalnicze o zasięgu poziomym przestrzeni roboczej (bez efektora) wynoszącym ok. $1500 \mathrm{~mm}$. Jednostki znacznie większe stanowią nieliczne wyjątki, np. QIROX 7 firmy CLOOS o podstawie powiększonej o dodatkową, siódmą oś, czy przedłużony M-710iC/20L firmy Fanuc o maksymalnym zasięgu $3110 \mathrm{~mm}$. Podczas wielu zadań spawalniczych zachodzi potrzeba dalszego zwiększenia zasięgu, osiągana za pomocą układów lokomocyjnych, np. torów jezdnych. Z tego względu najrzadziej stosowane będą jednostki najmniejsze, o zasięgu poniżej $1000 \mathrm{~mm}$. Wykorzystywane są przede wszystkim do zadań transportowych (pakowanie, paletyzacja), obsługowych i pomocniczych oraz przy budowie stanowisk edukacyjnych. W tym ostatnim przypadku, przy odpowiedniej organizacji stanowiska, mogą nie być konieczne rozbudowane zabezpieczenia przed dostępem w obszar pracy robota (rys. 4a). Z drugiej strony, tak mała jednostka ograniczy możliwości badawcze podczas spawania większych obiektów oraz pracę na dodatkowych, np. dostawianych stołach i pozycjonerach (rys. 4b).

Od dłuższego czasu obserwuje się tendencję do specjalizowania robotów pod kątem określonych procesów technologicznych. Dotyczy to w szczególności robotów o strukturze antropomorficznej, modyfikowanych zarówno w zakresie konstrukcyjnym (roboty o różnej liczbie osi, uszczelnione, z wbudowanym osprzętem procesowym itp.), jak i programowym (specjalne komendy języka programowania, wbudowane funkcje sensoryczne itp.). W odniesieniu do spawania łukowego można obecnie mówić o trzech poziomach dostosowania [2,5]:

- roboty uniwersalne ogólnego przeznaczenia (niespecjalizowane), spełniające ogólne wymagania techniczne (obecnie grupa najmniej polecana);

- roboty specjalizowane, przystosowane przez producenta do spawania i procesów pokrewnych;

- roboty specjalne, dedykowane prawie wyłącznie do spawania i procesów pokrewnych (np. system TAWERS firmy Panasonic).

W warunkach laboratorium badawczego oraz prowadzenia zajęć edukacyjnych najodpowiedniejszy wydaje się wariant specjalizowany pod kątem dominujących procesów, $\mathrm{np}$. spawalniczych, o ile jednak nie ograniczy to możliwości szerszego wykorzystania maszyny. Taką funkcjonalnością wyróżniał się IRp-6, już w połowie lat 90 . wyposażony w szereg programowych funkcji spawalniczych $[5,11]$, jednak nieograniczających szerszego wykorzystania. Z drugiej strony, część eksploatowanych w Zakładzie Inżynierii Spajania robotów Kawasaki nie posiadała dedykacji spawalniczej co nie przeszkadzało $\mathrm{w}$ realizacji tego typu zadań, jednak za cenę dodatkowej pracy przy sprzęcie i programie roboczym. W takim przypadku nie były możliwe, lub były trudne do osiągnięcia, działania awaryjne podczas błędów jarzenia łuku, np. reakcja na jego opóźnienie lub nagłe przerwanie.

Istotne zwiększenie zdolności do docierania do trudnodostępnych miejsc spawania oraz jego prowadzenie w najdogodniejszych pozycjach wymaga użycia dodatkowych 

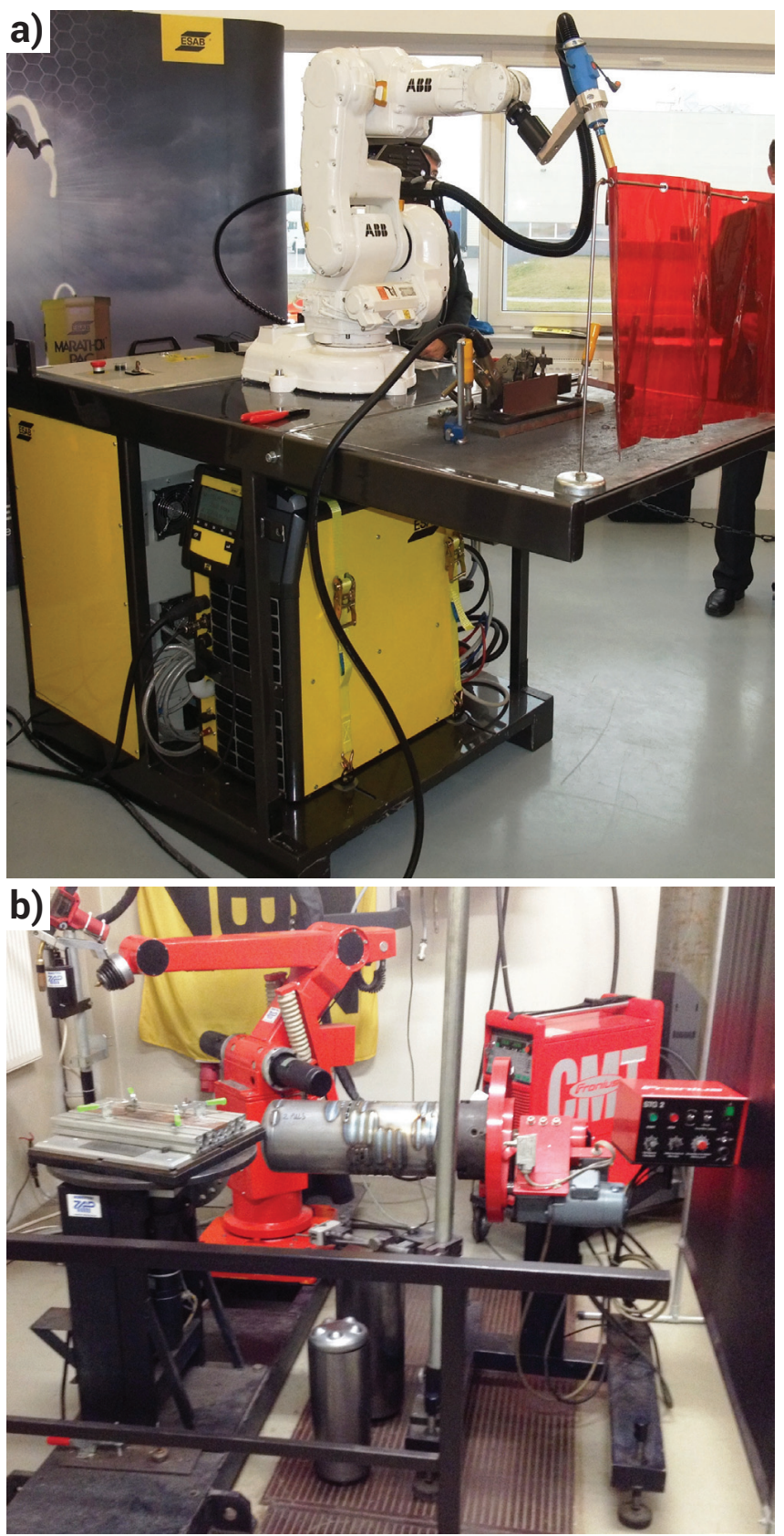

Rys. 4. Stanowiska edukacyjne: a) kompaktowe w oparciu o niewielki robot ABB i sprzęt spawalniczy firmy ESAB, b) z robotem IRp-6 i dostawianym dodatkowym pozycjonerem

Fig. 4. Educational setups: a) compact based on small $A B B$ robot and welding equipment made by ESAB, b) with IRb- 6 robot and additional positioner

manipulatorów - tzw. zewnętrznych osi robota. Są to odrębne maszyny manipulacyjne współdziałające z robotem, sterowane w oparciu o ten sam program użytkowy, np. pod postacią wieloosiowych pozycjonerów manipulujących spawanymi elementami. Od zewnętrznych osi oczekuje się wysokiej dokładności i obciążalności, zdolności do pracy w pełni zsynchronizowanej z ruchami robota, a pożądane właściwości użytkowe osiągane są m.in. dzięki odpowiedniej strukturze kinematycznej oraz właściwościom układów napędowych i sterowania. Znacznym utrudnieniem jest brak jakiejkolwiek unifikacji serwonapędów elektrycznych, w tym kodów sterujących, pomiędzy producentami robotów - każda zewnętrzna oś zdolna do pełnej synchronizacji z robotem wymaga zastosowania napędu (silnik, przekładnia, serwo-wzmacniacz, oprogramowanie) dedykowanego przez producenta danego robota. Wykorzystanie maszyny niekompatybilnej z robotem, o ile będzie możliwe do zrealizowania, zawsze skutkować będzie istotnym ograniczeniem funkcjonalnym [7].
Wyposażenie robota laboratoryjnego i edukacyjnego w jakąkolwiek zewnętrzną oś, nawet jeśli nie jest niezbędna z uwagi na wykonywanie głównie prostych połączeń testowych, jest nie do przecenienia. Wieloletnie doświadczenie autorów z tego typu konstrukcjami potwierdza wysoką użyteczność pozycjonerów dwuosiowych z obrotowym i pochylanym stołem roboczym. W większości dotychczas stosowanych maszyn obrót stołu posiada pełną synchronizację z robotem, zaś pochylenie realizowane jest ręcznie, zwykle w zakresie $0 \div 90^{\circ}$ (wyjątek stanowił pozycjoner dostarczony z pierwszym, wypożyczonym robotem Kawasaki, rys. 2a).

\section{Specjalistyczny robot kartezjański}

Układ kartezjański (prostokątny) utworzony jest przez trzy, wzajemnie prostopadłe osie - pary kinematyczne postępowe A1, A2 i A3 - rysunek 5. Zwykle też nie jest uzupełniany o jakiekolwiek dodatkowe osie w układzie kiści (nadgarstka) do orientacji kątowej efektora. Wysoka sztywność, łatwość sterowania i wizualizacji pracy tego typu konstrukcji okupione są niewielkimi możliwościami manipulacyjnymi, w tym omijania przeszkód. Ten rodzaj struktury wykorzystywany jest przede wszystkim w prostych robotach i manipulatorach stałoprogramowych przeznaczonych do zadań transportowych i obsługowych oraz w dużych robotach paletyzujących, zwłaszcza w odmianie odwróconej (bramowej, suwnicowej).

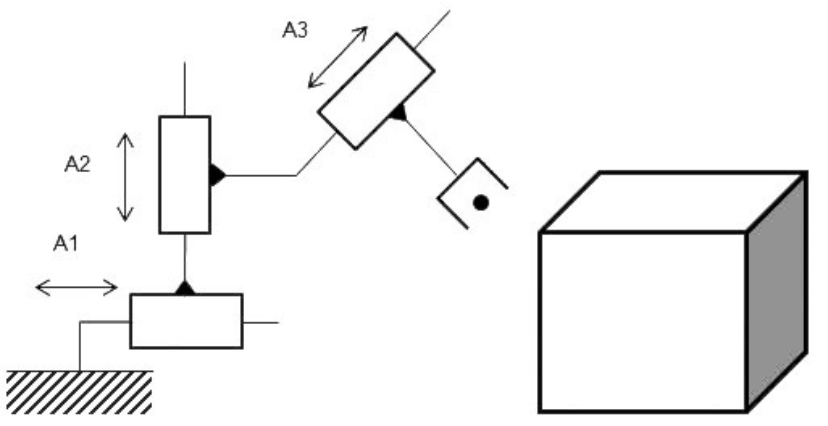

Rys. 5. Schemat struktury kartezjańskiej oraz zarys przestrzeni roboczej

Fig. 5. The scheme of Cartesian structure with working range area

W odniesieniu do procesów spawalniczych tego typu struktura pozbawiona układu orientowania (pochylania) narzędzia wydaje się nie mieć bezpośredniego zastosowania, co znajduje potwierdzenie w praktyce. Z drugiej jednak strony istnieją takie procesy jak np. napawanie z przetapianiem proszku podawanego $\mathrm{w}$ strumień plazmy, wymagające co najmniej zmechanizowanego prowadzenia głowicy roboczej, gdzie w większości aplikacji może nie zachodzić potrzeba, a wręcz nie jest możliwe jej odchylanie od pionu.

W ramach modernizacji stanowiska do napawania plazmowego podjęto decyzję o modernizacji pierwotnie eksploatowanego, prostego słupowysięgnika do zmechanizowanego prowadzenia plazmotronu w dwóch osiach (X i Z, rys. 6).

Opracowano i zrealizowano, za pośrednictwem specjalistycznego producenta, koncepcję specjalistycznego trzyosiowego robota kartezjańskiego (ruchy w kierunkach $X, Y$ i Z), wspomaganego dwoma zewnętrznymi osiami - w pełni zintegrowanym obrotowym pozycjonerem oraz niezależnie sterowanym, odzyskanym z pierwotnego stanowiska programowalnym oscylatorem (ruch w kierunku Y) - rysunek 7.

Konstrukcja nośna robota wykonana została ze stalowych profili ceowych w układzie kratownicowym, zapewniającym wysoką sztywność. Napędy poszczególnych osi zrealizowano w oparciu o elektryczne silniki krokowe, przekładnie śrubowo-toczne i prowadnice liniowe $\mathrm{w}$ formie szlifowanych wałków (rys. 8). 


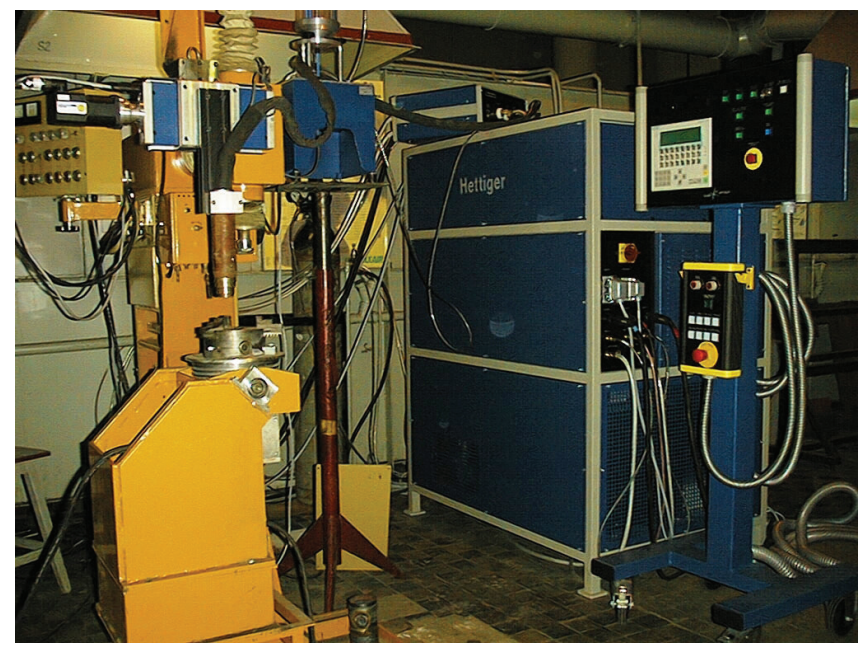

Rys. 6. Dotychczasowe stanowisko do napawania plazmowego (wycofany z eksploatacji manipulator produkcji ZDIS)

Fig. 6. Previous setup used for plasma surfacing (withdraw from production ZDIS manipulator)

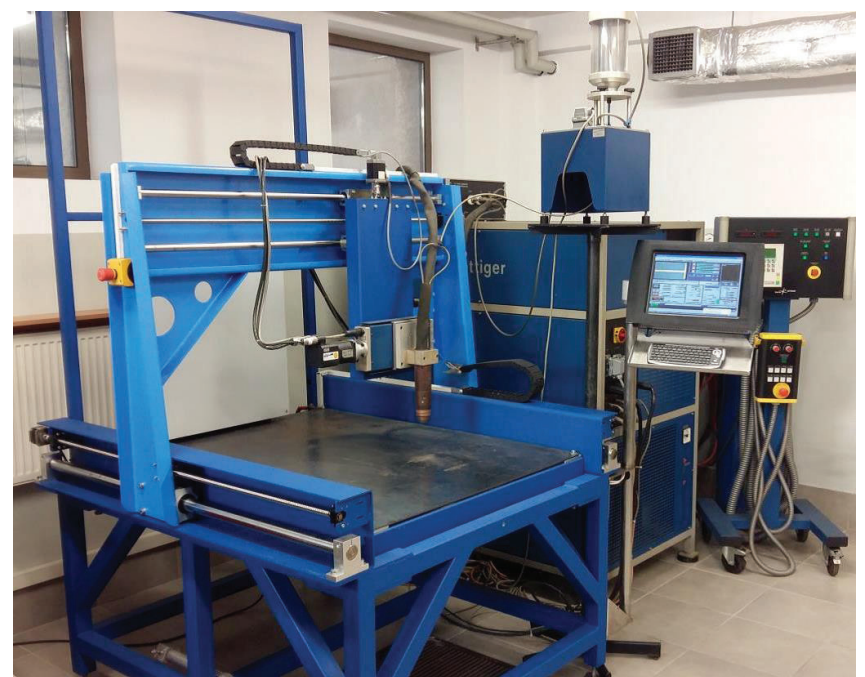

Rys. 7. Trzyosiowy manipulator kartezjański do napawania (widok bez pozycjonera)

Fig. 7. 3-axis Cartesian manipulator used for surfacing (view without positioner)

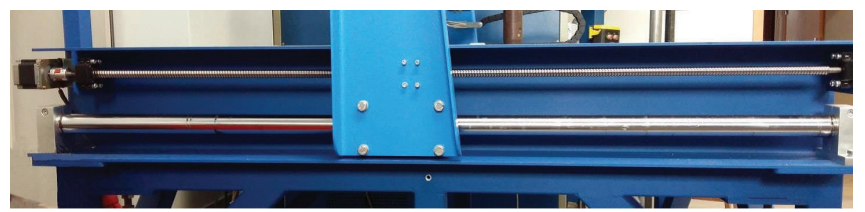

Rys. 8. Widok mechanizmu napędowego ruchu manipulatora w kierunku osi X

Fig. 8. The view of driving mechanism of manipulator in $\mathrm{x}$-ax direction

Układ sterowania oparto na komputerze PC i umieszczono w szafie sterowniczej w tylnej części manipulatora. Programowanie, w oparciu o G-kod pod kontrolą programu narzędziowego $\mathrm{MACH}$, odbywa się za pośrednictwem bezprzewodowej klawiatury oraz kolorowego monitora przemysłowego (rys. 9).

W skład stanowiska wchodzą następujące, główne komponenty:

- zasilacz łuku plazmowego PTA 301 Control M firmy Hettiger (tabl. I),

- podajnik proszku,

- układ sterowania źródła łuku plazmowego na bazie sterownika PLC Simens S7-300,

- plazmotron HPM 302,

- programowalny robot w układzie kartezjańskim (tabl. II),

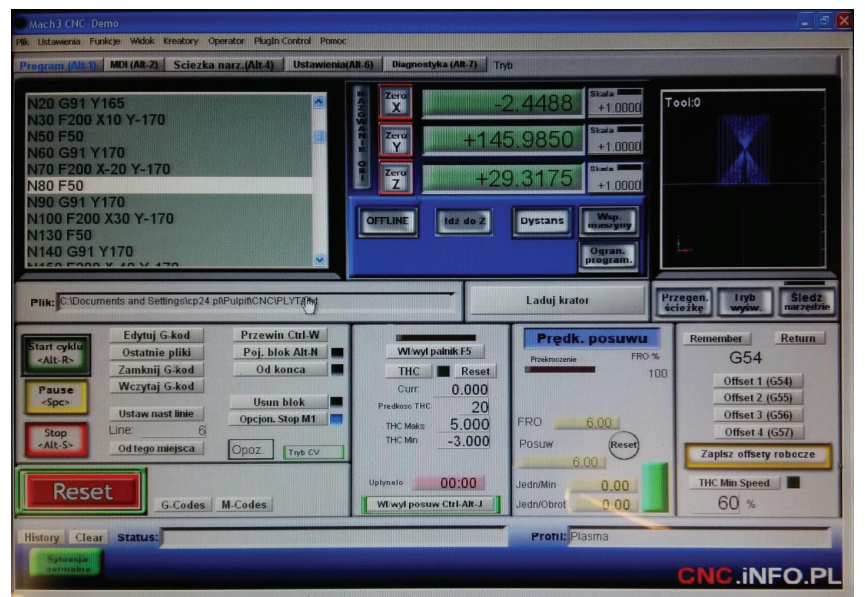

Rys. 9. Widok ekranu głównego podczas programowania robota Fig. 9. The view of main screen during robot programming

Tablica I. Podstawowe parametry zasilacza PTA 301 z plazmotronem HPM 302 (Hettiger)

Table I. Basic technical data of supply unit PTA 301 with HPM plasma torch (Hettiger)

\begin{tabular}{|c|c|}
\hline Parametr & $\begin{array}{c}\text { Zakres regulacji } \\
\text { i jednostka }\end{array}$ \\
\hline Natężenie prądu łuku pilotującego & $5 \div 100 \mathrm{~A}$ \\
\hline Natężenie prądu łuku głównego & $15 \div 300 \mathrm{~A}$ \\
\hline Wydatek proszku & $5 \div 85 \mathrm{~g} / \mathrm{min}$ \\
\hline Zakres ruch oscylacyjnego & $0 \div 80 \mathrm{~mm}$ \\
\hline Prędkość ruch oscylacyjnego & $250 \div 3000 \mathrm{~mm} / \mathrm{min}$ \\
\hline Wydatek gazu plazmotwórczego & $0,5 \div 5 \mathrm{l} / \mathrm{min}$ \\
\hline Wydatek gazu osłonowego & $1,5 \div 30 \mathrm{l} / \mathrm{min}$ \\
\hline Wydatek gazu transportującego proszek & $0,5 \div 10 \mathrm{l} / \mathrm{min}$ \\
\hline
\end{tabular}

Tablica II. Podstawowe parametry robota kartezjańskiego Table II. Basic technical data of Cartesian robot

\begin{tabular}{|c|c|}
\hline Parametr & $\begin{array}{c}\text { Wielkość, cecha } \\
\text { i jednostka }\end{array}$ \\
\hline Przestrzeń robocza & $1000 \times 1000 \mathrm{~mm}$ \\
\hline Liczba sterowanych osi & $4(\mathrm{X}, \mathrm{Y}, \mathrm{Z}+$ pozycjoner $)$ \\
\hline Powtarzalność pozycjonowania & $\pm 0,05 \mathrm{~mm}$ \\
\hline $\begin{array}{c}\text { Maksymalna prędkość ruchów } \\
\text { roboczych }\end{array}$ & $1 \mathrm{~m} / \mathrm{min}$ \\
\hline $\begin{array}{c}\text { Maksymalna prędkość ruchów } \\
\text { ustawczych }\end{array}$ & $3 \mathrm{~m} / \mathrm{min}$ \\
\hline Obciążalność stołu & 200 kg \\
\hline Stół roboczy & $\begin{array}{c}\text { wymienny z możliwością } \\
\text { kompensacji odkształceń } \\
\text { termicznych }\end{array}$ \\
\hline
\end{tabular}

- układ sterowania ze zintegrowanym z korpusem robota ekranem i klawiaturą,

- oscylator (sterowany z poziomu sterownika źródła łuku plazmowego),

- pozycjoner obrotowy (sterowany z poziomu sterownika robota). 

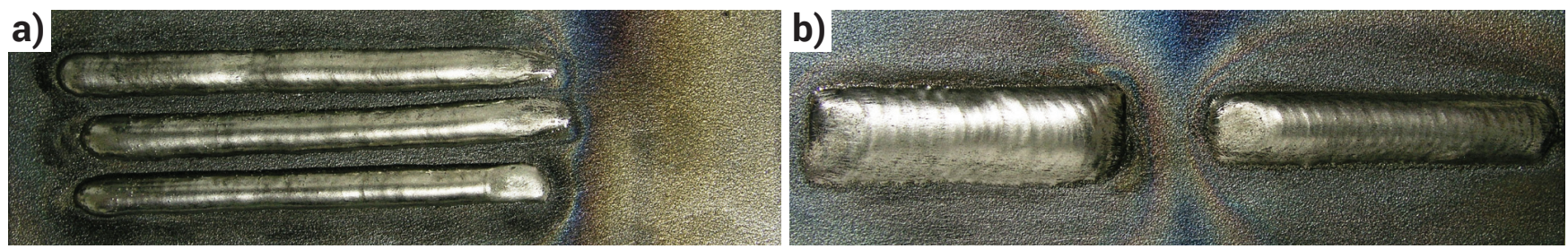

Rys. 10. Napoiny testowe ze stopu NiCrSiB: a) bez oscylacji, prędkość napawania - od dołu: 80, 100 i $120 \mathrm{~mm} / \mathrm{min}$, b) prędkość napawania $50 \mathrm{~mm} / \mathrm{min}$ z oscylacją - od lewej: $12 \mathrm{~mm}$ i $8 \mathrm{~mm}$

Fig. 10. Test surface welds of NiCrSiB alloy: a) without electrode oscillation, welding speed $80 \mathrm{~mm}$ (down), 100 and $120 \mathrm{~mm} / \mathrm{min}$, b) with electrode oscillation $12 \mathrm{~mm}$ (left) and $8 \mathrm{~mm}$, welding speed $50 \mathrm{~mm} / \mathrm{min}$
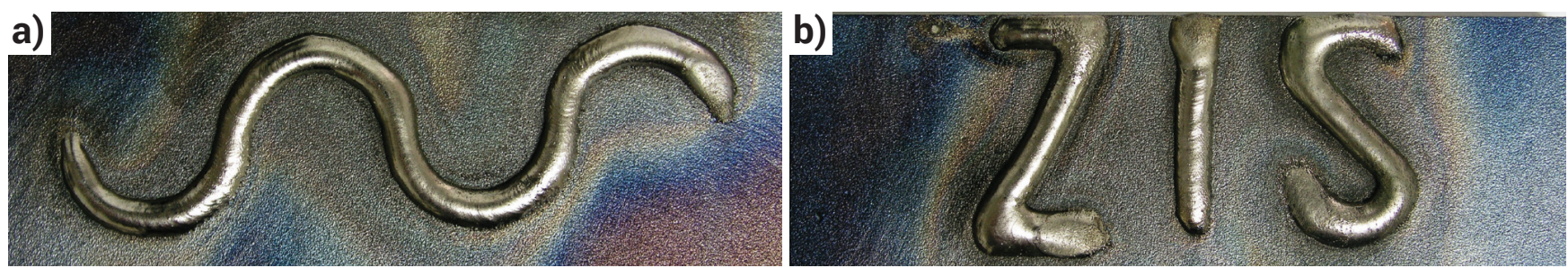

Rys. 11. Napoiny testowe wykonane z interpolacją: a) kołową, b) kołową i liniową

Fig. 11. Test surface welds made with: a) circle interpolation, b) circle and line interpolation

Z uwagi na niewielkie prędkości oraz zakres ruchu plazmotronu, niewykraczający poza obszar stołu i ramy nośnej, nie zainstalowano specjalnych zabezpieczeń chroniących przed wtargnięciem w obszar pracy robota. Wyłączniki bezpieczeństwa, zatrzymujące pracę robota oraz odłączające napędy, umieszczono po obu stronach pionowej ramy manipulatora. Osłonę przed promieniowaniem łuku stanowią przenośne parawany z filtrem optycznym.

Z punktu widzenia badawczego przeznaczenia nowego stanowiska, najistotniejsze było potwierdzenie jego przydatności do zadań z zakresu napawania plazmowego oraz procesów pokrewnych. Nowością w stosunku do dotychczas eksploatowanego prostego manipulatora, wymagającą szczegółowego zbadania, była możliwość programowania złożonych trajektorii z wykorzystaniem interpolatorów liniowego i kołowego. W tym celu wykonano serię badań wstępnych w szerokim zakresie parametrów, tj. prędkości ruchów roboczych oraz stopnia złożoności trajektorii ruchu plazmotronu. Napoiny wykonywano bez i z ruchami oscylacyjnymi. Zapewnienie stabilnej prędkości ruchu roboczego plazmotronu gwarantuje otrzymywanie napoin o powtarzalnej geometrii. Jest to szczególnie istotne przy napawaniu precyzyjnym, np. krawędzi form wtryskowych.

Na rysunku 10 przedstawiono widok napoin wykonanych dla różnych parametrów procesu. Makroskopowo widoczna jest stała szerokość ściegów, co przy ustalonych parametrach procesu możliwe jest do uzyskania poprzez zapewnienie stałej prędkości napawania. Przemieszczanie się plazmotronu wg interpolacji kołowej i liniowej w płaszczyźnie roboczej XY także gwarantuje otrzymywanie ściegów o powtarzalnym kształcie - rysunek 11. Wysoka dokładność pozycjonowania i zarazem stabilność ruchów roboczych manipulatora znacząco rozszerza zakres możliwości eksploatacyjnych i umożliwia napawanie elementów o złożonym kształcie.

Stabilna prędkość ruchów roboczych manipulatora w zakresie większych prędkości zapewnia nie tylko powtarzalną geometrię ściegów napawanych, ale również powoduje wzrost wydajności napawania, jak również otrzymywanie napoin o korzystnej mikrostrukturze i mniejszej strefie wpływu ciepła. W warunkach szybko przemieszczającego się skoncentrowanego strumienia plazmy krystalizacja ciekłego jeziorka również postępuje z większą prędkością. To z kolei zapewnia otrzymywanie napoin o drobnoziarnistej strukturze gwarantującej wysokie właściwości eksploatacyjne - rysunek 12a. Natomiast w powłokach o strukturze kompozytowej, krótki czas kontaktu cząstek fazy umacniającej z ciekłą osnową ogranicza lub wręcz uniemożliwia ich rozpuszczanie (rys. 12b), a odporność na zużycie ścierne takiej napoiny jest bardzo wysokie [10].

Przeprowadzono także udane próby napawania metodą MIG/MAG w oparciu o źródło serii TPS firmy Fronius, z uchwytem elektrodowym zamocowanym w miejsce plazmotronu.
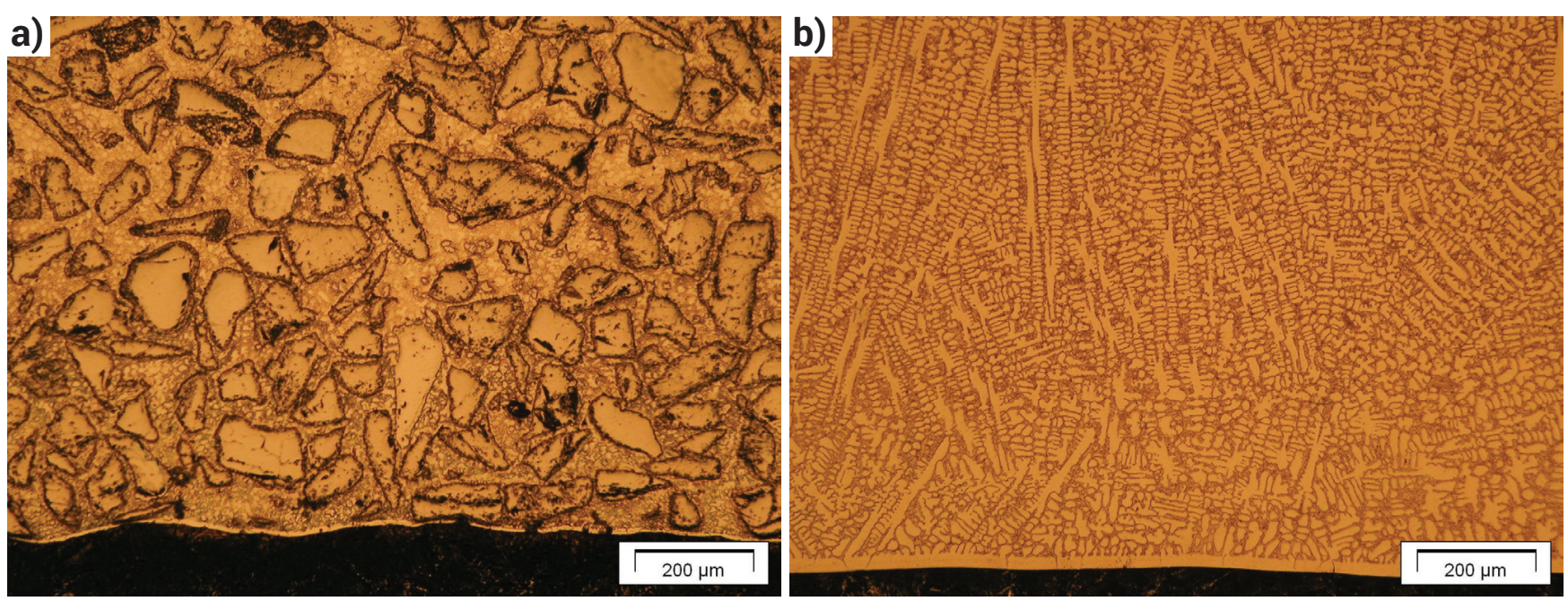

Rys. 12. Mikrostruktury napoin testowych z proszku: a) NiCrSiB, b) stopu Ni+40\%WC

Fig. 12. Test surface welds microstructure, filler material: a) NiCrSiB and b) $\mathrm{Ni}+40 \% \mathrm{WC}$ powders 


\section{Uniwersalna cela spawalnicza}

Zużyty wieloletnią eksploatacją IRp-6 zastąpiono robotem spawalniczym ArcMate 0iB z kontrolerem R-30iB Mate (FANUC), uzupełnionym o moduł zewnętrznej osi (pozycjoner) oraz trzy stanowiska do programowania w trybie off-line, o głównych parametrach:

- robot 6-osiowy, antropomorficzny;

- udźwig $3 \mathrm{~kg}$;

- powtarzalność pozycjonowania $\pm 0,08 \mathrm{~mm}$;

- masa jednostki mechanicznej (manipulatora) 145 kg;

- konwencjonalny nadgarstek (nieprzelotowy);

- kontroler (układ sterowania) z dedykacją spawalniczą;

- dwuosiowy pozycjoner spawalniczy (obrót stołu jako zewnętrzna oś robota, ręczne pochylanie stołu z blokadą co $15^{\circ} \mathrm{W}$ zakresie $0 \div 90^{\circ}$ ) o powtarzalności pozycjonowania $\pm 0,1 \mathrm{~mm}$.

Na etapie realizacji zamówienia możliwe było szczegółowe uzgadnianie i modyfikacja komponentów indywidualnie dorabianych przez integratora (ZAP Robotyka z Ostrowa Wlkp.), takich jak rama nośna stanowiska czy korpus i funkcje pozycjonera. Do realizacji poszczególnych zadań zaangażowano także licznych studentów [12,13].

Z punktu widzenia montażu robota ważne jest zapewnienie jego sztywnego zamocowania do podłoża oraz względem tych maszyn i urządzeń stanowiska, które mają bezpośredni wpływ na proces technologiczny. Powtarzalne i dokładne pozycjonowanie ramienia robota względem np. pozycjonera i zamocowanych na nim spawanych elementów praktycznie wyklucza osobny montaż tych urządzeń. Dobrym rozwiązaniem jest ich umieszczenie na wspólnej ramie, platformie lub podeście $[5,8]$.

Elementy konstrukcyjne łączące mały lub średniej nośności robot przemysłowy, np. spawalniczy, z pozycjonerem, mogą przyjmować różne formy [8]:

- podestu, będącego jednocześnie częścią konstrukcyjną pozycjonera;

- przestrzennej ramy, np. w formie belki o przekroju prostokątnym;

- podłogi, będącej podstawą kompaktowego stanowiska, również kabinowego.

Konstrukcje nośne robotów powinny mieć odpowiednią sztywność, gwarantującą minimalne odkształcenie (w tym wygięcie) wynikające z obciążenia, przede wszystkim robotem i pozycjonerem, a także siłami i momentami gnącymi wynikającymi z przyspieszenia robota w czasie ruchów ustawczych i roboczych. Dla nowego stanowiska założono, że rama nośna, wspólna dla robota i dwuosiowego pozycjonera, nie będzie mocowana do podłoża, a jedynie zaopatrzona w regulowane nogi, z możliwością swobodnego manewrowania zestawem w pomieszczeniu. $W$ tym celu konieczne było spełnienie szeregu warunków:

- wysoka sztywność z uwagi na obciążenie robotem i pozycjonerem;

- wysoka sztywność z uwagi dynamiczne ruchy ramienia robota;

- kompaktowe wymiary nieutrudniające dostępu do programowanego stanowiska;

- możliwość przeprowadzenia przewodów zasilających i sterujących wewnątrz ramy.

Ostatecznie uzgodniono wykonanie ramy w formie litery $\mathrm{T}$, z poprzeczną belką stabilizującą umieszczoną na wysokości podstawy robota, stabilizującą stanowisko podczas jego dynamicznych ruchów. Dodatkowym założeniem była możliwość przemocowywania robota i pozycjonera w obrębie przygotowanych gniazd montażowych. W przypadku pozycjonera także z możliwością jego obracania co $90^{\circ}$, w celu zmiany płaszczyzny pochylenia stołu. Wstępna postać ramy przedstawiona została na rysunku 13.

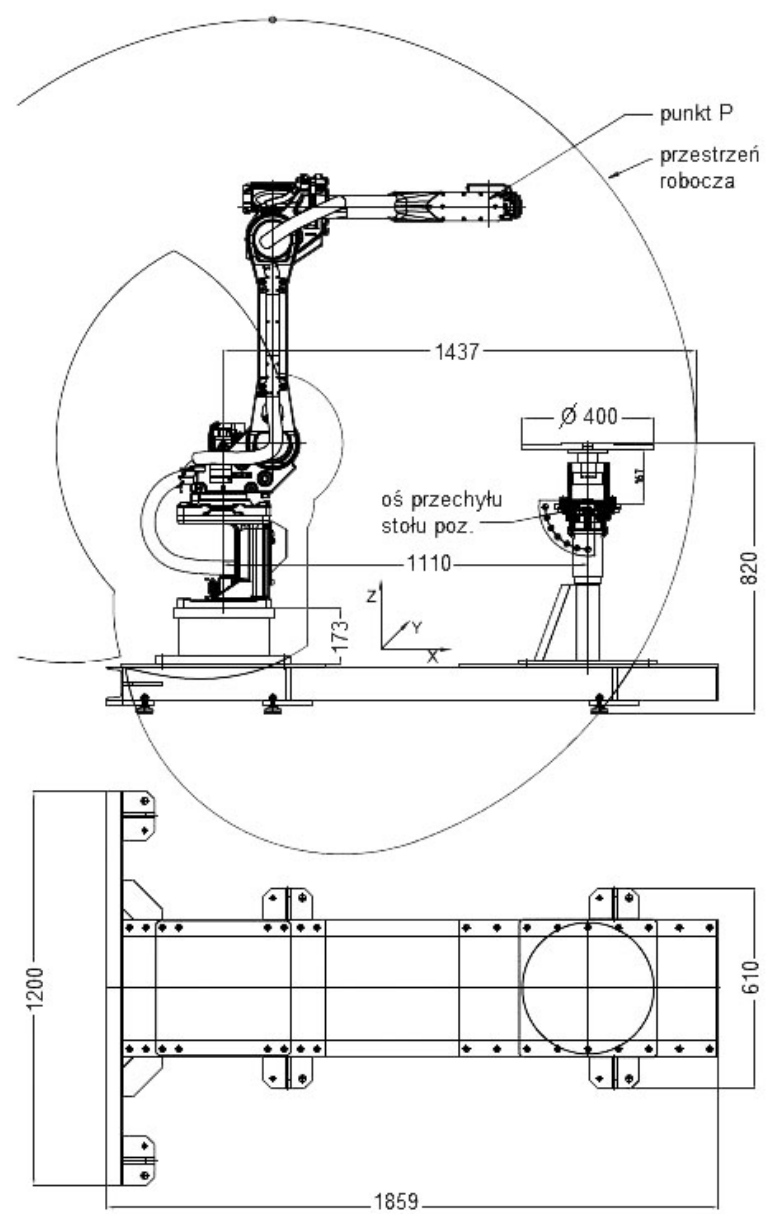

Rys. 13. Wstępna postać uzgodnionej ramy nośnej stanowiska z zaznaczoną przestrzenią roboczą robota Arc Mate OiB (Fanuc)

Fig. 13. Preliminary design of carrying frame of Arc Mate OiB robot (Fanuc) setup with the range of working area shown

Na podstawie posiadanej, podobnej ramy dla robota IRp-6, a także wcześniejszych analiz wytrzymałościowych metodą elementów skończonych MES dla tego typu konstrukcji $[6,8]$, w tym projektu dyplomowego bezpośrednio poprzedzającego wykonanie ramy [12] przyjęto następujące założenia konstrukcyjne:

- korpus ramy z ceowników 100 × 50 × 6 mm (wariant odrzucony) lub z rur prostokątnych $100 \times 50 \times 5$ mm (rys. 14),

- orientacja profili w ramie - dłuższy bok w pionie,

- rama spawana z dodatkowymi panelami wypełniającymi,

- osiem punktów podparcia z regulowanymi nogami (z możliwością mocowania do podłoża),

- robot przesuwany (przemocowywany) w osi X co $50 \mathrm{~mm}$ w zakresie $\pm 100 \mathrm{~mm}$,

- pozycjoner przesuwany (przemocowywany) w osi $\mathrm{X}$ co $92,5 \mathrm{~mm}$ w zakresie $\pm 185 \mathrm{~mm}$,

- pozycjoner obracany (przemocowywany) wokół osi Z co $90^{\circ}$.

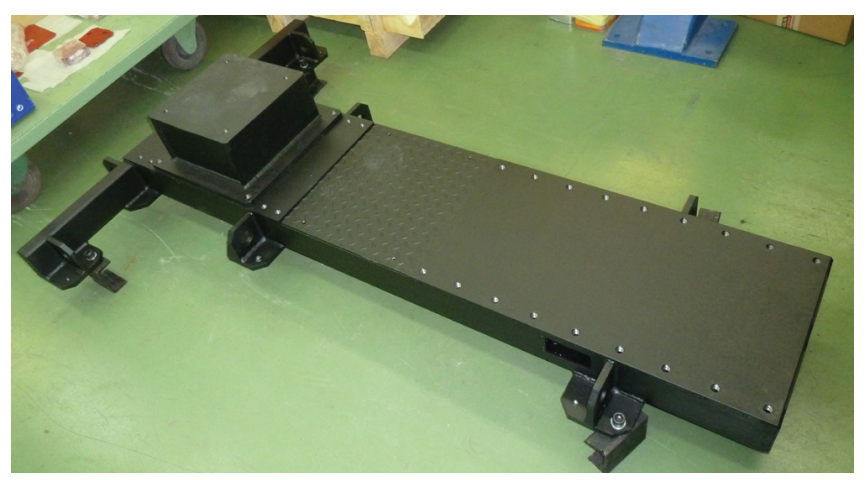

Rys. 14. Zbudowana rama nośna stanowiska

Fig. 14. Ready setup carrying frame 
Zrealizowany projekt ramy nośnej, w tym zakres przestawiania (przemocowywania) robota i pozycjonera były przedmiotem szeregu badań i analiz. Funkcje ramy zweryfikowano w warunkach modelowania i symulacji off-line w środowisku ROBGUIDE firmy Fanuc [13]. Potwierdzono, że pomimo niewielkiej powierzchni stanowiska, osiągnięty został wysoki poziom elastyczności i komfortu pracy (rys. 15).

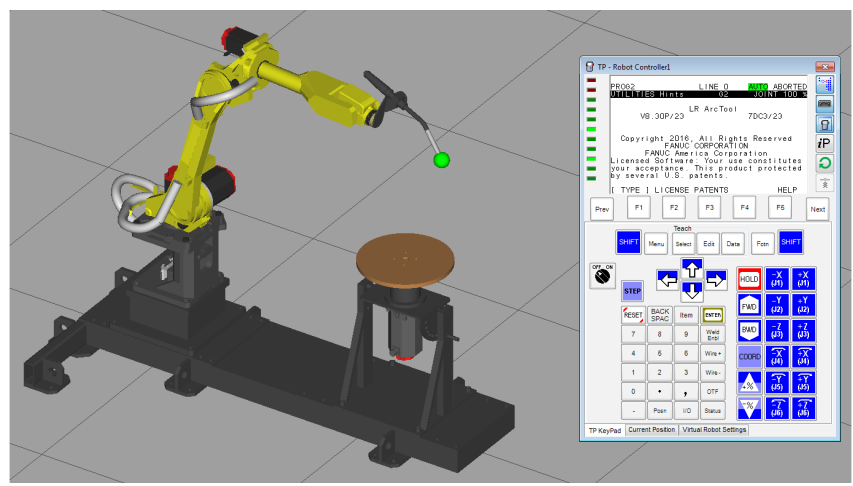

Rys. 15. Stanowisko modelowane w środowisku off-line ROBGUIDE (Fanuc) [13]

Fig. 15. Model setup in off-line ROBGUIDE (Fanuc) [13]

Znaczna dynamika i zasięg nowego robota w połączeniu z modułem zewnętrznej osi wymagały nie tylko prawidłowego rozmieszczenia i instalacji mechanicznej, ale przeprowadzenia analizy zagrożeń i zastosowania odpowiednich zabezpieczeń oraz utworzenia systemu połączeń sygnałowych pomiędzy poszczególnymi urządzeniami.

Podczas analizy zagrożeń skupiono się przede wszystkim na pracy robota i pozycjonera. Szkodliwe działanie procesu spawalniczego (łuk, pyły i gazy, rozpryski itp.) minimalizowane jest $w$ ramach infrastruktury laboratorium takimi środkami jak: klimatyzacja i wentylacja ogólna, odciągi pyłów i gazów, parawany, środki ochrony osobistej itp.

Analizę ryzyka związanego z pracą robota przeprowadzono w oparciu o EN ISO 13849-1 na podstawie trzech czynników: stopnia obrażeń S (S1 - stopień lekki, nietrwałe i S2 - stopień poważny, śmierć), częstotliwości narażenia na ryzyko $F$ (F1 - rzadko, okazjonalnie i/lub krótkotrwale, F2 - często i/lub długotrwale) oraz możliwości uniknięcia bądź ograniczenia obrażeń P (P1 - możliwe, P2 - niemal niemożliwe). Określając wartość S, F i P można uzyskać wymagany parametr $P L_{r}$ (w skali od a - małe ryzyko do e - duże ryzyko), konieczny do oszacowania źródła ryzyka (rys. 16) [1].

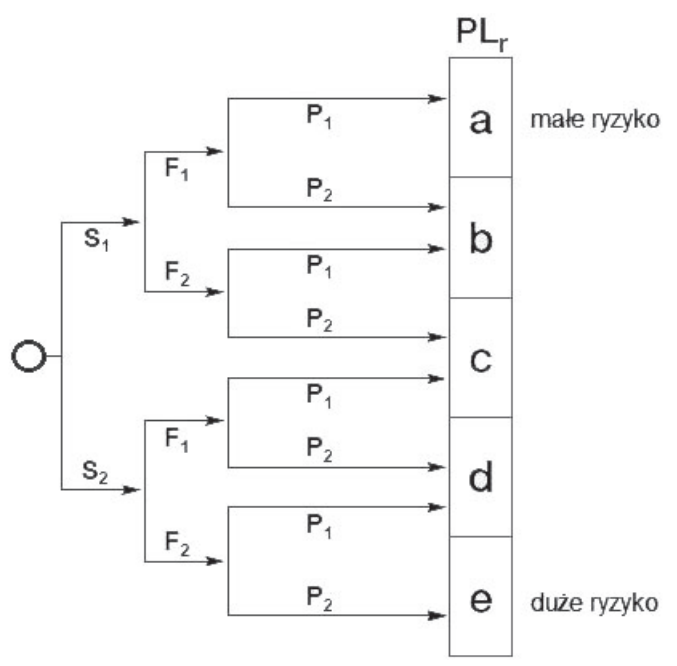

Rys. 16. Diagram do określania ryzyka $\mathrm{PL}_{r}[1]$ Fig. 16. Diagram for risk assessment $P L_{r}[1]$
Specyfika stanowiska laboratoryjnego, na którym badane będą zarówno procesy spawalnicze w warunkach zbliżonych do przemysłowych, jak i jego poszczególne komponenty (robot, pozycjoner, źródła zasilające łuk, systemy bezpieczeństwa) przy niemożliwych do oszacowania parametrach eksploatacyjnych (ilość cykli w ciągu roku, czas cyklu itp.) wykluczają możliwość przeprowadzenia szczegółowych obliczeń na potrzeby systemów bezpieczeństwa. Z drugiej strony, zrealizowany został wariant organizacyjny stanowiska wymagający systematycznego przebywania osób w obszarze strefy zagrożenia (strefie niebezpiecznej) generowanej przez robot - załadunek, rozładunek, bieżąca obsługa. Analizując składowe PLr (rys. 16) ustalono poziom ryzyka jako wysoki - c, ponieważ:

- samoczynne uruchomienie się maszyny nie spowoduje poważnych obrażeń (S1);

- części do spawania, próbki itp. będą ładowane do wnętrza stanowiska (na stole pozycjonera) ręcznie, a zaburzenia robota i osprzętu da się usunąć tylko w strefie zagrożenia (F2);

- operator nie ma możliwości uniknięcia obrażeń - robot porusza się szybko (P2).

Konieczność redukcji tak wysokiego poziomu ryzyka wymagała opracowania systemu bezpieczeństwa i procedur bezpiecznego używania maszyn. Zastosowano m.in. bariery stałe, kurtynę świetlną zsynchronizowaną z trybami pracy stanowiska za pośrednictwem przekaźnika bezpieczeństwa, szereg przycisków zatrzymania awaryjnego inny sprzęt zabezpieczający (rys. 17).

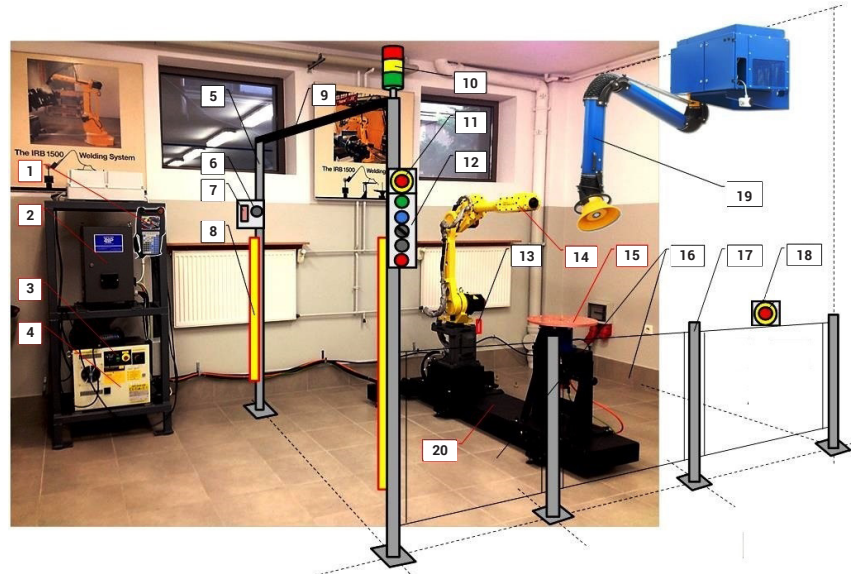

Rys. 17. Stanowisko laboratoryjne z systemem zabezpieczeń (opis w tekście)

Fig. 17. Laboratory setup with safety system protection (explanation in text)

Zrealizowana koncepcja obejmuje następujące, główne komponenty (rys. 17):

1. Ręczny panel programowania (ang. Teach Pendant).

2. Szafa sterownika zewnętrznej osi robota (pozycjonera).

3. Kontroler robota - panel operatora "1".

4. Kontroler robota - jednostka centralna R-30iB Mate.

5. Słupy wysokie osłon stanowiska.

6. Kaseta przekaźnika bezpieczeństwa - wyłącznik kluczykowy funkcji MUTE.

7. Kaseta przekaźnika bezpieczeństwa - przekaźnik UE10-30S (SICK).

8. Kurtyna świetlna: JANUS J 3B TRX E/R (ReeR).

9. Koryto przewodów sterujących.

10. Wieża sygnalizacyjna (czerwona - błąd, pomarańczowa - tryb ręczny, zielona - automatyczny).

11. STOP AWARYJNY - przycisk.

12. Panel operatora "2" (dorabiany).

13. Przekaźnik funkcji MUTE na korpusie robota. 
14. FANUC Arc Mate OiB.

15. Pozycjoner dwuosiowy (pochylanie i obrót stołu).

16. Panele osłonowe (siatka).

17. Słupy niskie osłon stanowiska.

18. PRZERWANIE OSŁON - przycisk.

19. Wyciąg spawalniczy z filtrem.

20. Rama nośna stanowiska.

Kompromisem pomiędzy wysokim poziomem bezpieczeństwa a potrzebami prac badawczych oraz zajęć edukacyjnych było $\mathrm{m}$.in. zastosowanie niskich barier $\mathrm{z}$ wypełnieniem siatkowym uzupełnianych, o ile jest potrzeba, przestawianymi parawanami. Głowice spawalnicze mocowane będą za pośrednictwem złącza antykolizyjnego (CAT2, Binzel), a przestrzeń robocza robota ograniczona została dodatkową blokadą programową.

Wszystkie połączenia sygnałowe wykonano w oparciu o wejścia i wyjścia binarne standardu 0-24VDC, zarówno systemowe, jak i uniwersalne (rys. 18). Potencjał robota pozwala dodatkowo na zastosowanie komunikacji analogowej i sieciowej.

Do bezpiecznej obsługi stanowiska oraz realizacji różnorodnych zadań badawczych i edukacyjnych zaprojektowano autorski panel operatora "2" (poz. 11 i 12 na rys. 17, tabl. III).

Przekaźnik bezpieczeństwa uzupełniono o funkcję MUTE, blokującą sygnał przerwania kurtyny świetlnej podczas przewidzianego cyklem roboczym obsługowego wejścia w obszar pracy robota. MUTE działa tylko dla jednej, bezpiecznej pozycji robota (stojącego bokiem do osi stanowiska), potwierdzanej zamocowanym przy jego podstawie łącznikiem drogowym (rys. 18). W przypadku nieprzewidzianego ruchu robota jego zjechanie z łącznika powoduje natychmiastowe przekazanie informacji o wcześniejszym przecięciu kurtyny do kontrolera i wyłączenie napędów. Użycie funkcji MUTE znacząco przyspiesza standardową obsługę, jednak nieznacznie obniża poziom bezpieczeństwa - robot w chwili wejścia operatora ma nadal włączone napędy, a wieża świetlna pozostaje zielona (tabl. IV). Z tego względu wymaga dodatkowego przeszkolenia i jest aktywowana kluczykiem.

Wysoki poziom bezpieczeństwa wymagał zastosowania szeregu zabezpieczeń, zarówno działających automatycznie,

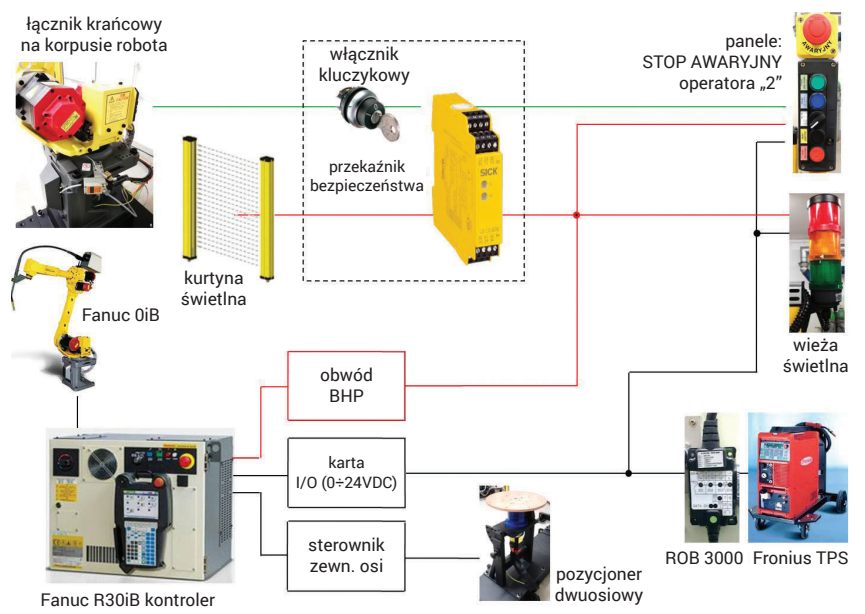

Rys. 18. Schemat ideowy połączeń sygnałowych stanowiska laboratoryjnego

Fig. 18. Signal connection scheme of laboratory setup

jak i aktywowanych ręcznie, wraz ze skuteczną sygnalizacją stanów pracy robota. Część zabezpieczeń zastosowano także z uwagi na edukacyjny i badawczy charakter stanowiska (tabl. V). Przycisk PRZERWANIE OSŁON podłączono do obwodu osłon stanowiska (ang. Fence Open). Złącze antykolizyjne podłączono do systemowego obwodu STOP AWARYJNY.

Należy w tym miejscu zaznaczyć, że podczas pracy w trybie nauczania systemy bezpieczeństwa działają w znacznie okrojonym zakresie. Nie działa system osłon z kurtyną świetlną oraz przycisk STOP PROGRAMU (HOLD), a podstawę bezpieczeństwa stanowi włącznik umieszczony na spodzie panelu programowania (ang. Deadman Switch) oraz zredukowana systemowo prędkość ruchu robota do poziomu 250 mm/s.

Podstawowe wyposażenie spawalnicze stanowiska tworzą dwa cyfrowe źródła firmy Fronius (TPS 2700ALU i TPS 2700CMT), uzupełnione o zewnętrzny panel sterujący RCU 5000i oraz interfejs ROB 3000. Wykorzystywane są ręczne i maszynowe uchwyty elektrodowe. Całość uzupełniają trzy stanowiska komputerowego programowania w trybie off-line.

Tablica III. Funkcje dodatkowego panelu operatora "2"

Table III. Operation possibilities of additional panel " 2 "

\begin{tabular}{|c|c|c|c|}
\hline \multirow{2}{*}{} & \multicolumn{2}{|c|}{ Numer wejścia DI, wyjścia DO i stan (NO/NC) } \\
\cline { 2 - 4 } & \multicolumn{2}{|c|}{ PRZYCISK } & LAMPKA \\
\hline START PROGRAMU & \multicolumn{2}{|c|}{ systemowy robota } & systemowa robota, zielona \\
\hline DALEJ (wykonanie cyklu) & \multicolumn{2}{|c|}{ DI 103, NO 103, NO, niebieska } \\
\hline P1 (podprogram, wariant 1) & DI 101, NO & DI 102, NC & - \\
\hline P2 (podprogram, wariant 2) & DI 101, NC & DI 102, NO & DO \\
\hline RESET KURTYNY & systemowy przekaźnika bezpieczeństwa & systemowa przekaźnika bezpieczeństwa, źótta \\
\hline STOP PROGRAMU (HOLD) & \multicolumn{2}{|c|}{ systemowy robota } & - \\
\hline
\end{tabular}

Tablica IV. Działania obsługowe z dodatkową funkcją MUTE

Table IV. Service operation with additional function MUTE

\begin{tabular}{|c|c|c|c|c|c|}
\hline \multirow{2}{*}{ Uruchomienie cyklu / tryb } & \multicolumn{4}{|c|}{ Kolejność wciśnięcia - o ile dotyczy } \\
\cline { 2 - 6 } & START PROGRAMU & DALEJ & RESET KURTYNY & RESET ROBOTA \\
\hline \multirow{2}{*}{ Pierwsze } & normalny & 3 & 4 & 1 & 2 \\
\cline { 2 - 6 } & MUTE & 3 & 4 & 1 & 2 \\
\hline \multirow{2}{*}{ Kolejne-po wejściu operatora } & normalny & nie dotyczy & 3 & 1 & 2 \\
\cline { 2 - 6 } & MUTE & nie dotyczy & 2 & 1 & nie dotyczy \\
\hline
\end{tabular}


Tablica V. Zabezpieczenia aktywowane podczas pracy automatycznej

Table V. Safety protection activated during automated operation

\begin{tabular}{|c|c|c|c|}
\hline \multirow{2}{*}{ Element bezpieczeństwa } & \multicolumn{3}{|c|}{ Reakcja } \\
\hline & Ramię robota & Napędy robota & Wieża świetlna \\
\hline STOP AWARYJNY, panel programowania & \multirow{4}{*}{ gwałtowne zatrzymanie } & \multirow{6}{*}{ wyłączone } & \multirow{6}{*}{ kolor czerwony } \\
\hline STOP AWARYJNY, kontroler & & & \\
\hline STOP AWARYJNY, panel operatora "2" & & & \\
\hline złącze antykolizyjne, narzędzia & & & \\
\hline Kurtyna świetlna - tryb normalny i MUTE & \multirow{3}{*}{ łagodne zatrzymanie } & & \\
\hline PRZERWANIE OSŁON (przycisk) & & & \\
\hline STOP PROGRAMU (HOLD) & & nie wyłączone & kolor zielony \\
\hline
\end{tabular}

\section{Podsumowanie}

Przedstawione konfiguracje nowych robotów - kartezjańskiego i antropomorficznego, mogą być swobodnie modyfikowane i dostosowywane do różnorodnych zadań badawczych i edukacyjnych.

Przy konfiguracji stanowisk szczególną uwagę zwrócono na zagadnienie bezpieczeństwa prac laboratoryjnych, podczas których roboty będą zarówno przedmiotem, jak i narzędziem badań.

Wszechstronne, badawcze i edukacyjne wykorzystanie robotów nie byłoby możliwe bez wsparcia licznych producentów i dystrybutorów urządzeń spawalniczych i robotów. Na szczególną uwagę zasługuje niedawno zakończona, wieloletnia obecność robotów Kawasaki w Zakładzie Inżynierii Spajania. Dotychczasowa, wzorowa współpraca z firmą ASTOR obejmowała trzy obszary działalności: dydaktykę, w tym pomoc w prowadzeniu prac przejściowych i dyplomowych, badania naukowe i współpracę o charakterze komercyjnym.

Dynamiczny rozwój urządzeń spawalniczych oraz robotów wyklucza możliwość kupowania wszystkich nowych jednostek na uczelnię, stąd idea czasowego użyczania nowych maszyn jest szczególnie ważna i warta docenienia. Mamy tym samym nadzieję na dalszą współpracę, zarówno z dotychczasowymi, jak i nowymi partnerami.

\section{Literatura}

[1] Bezpieczeństwo w systemach sterowania według normy EN ISO 13849-1. Bezpieczeństwo maszyn, Materiały firmowe ABB, 2012.

[2] Cegielski P.: Robot spawalniczy, Przegląd Spawalnictwa 1/2015, s. 65-66

[3] Cegielski P.: Analiza uwarunkowań zapewnienia prawidłowej trajektorii w zrobotyzowanych aplikacjach spawania tukowego MIG/MAG, Przegląd Spawalnictwa 8/2014, s. 34-40.

[4] Cegielski P.: Robot Kawasaki w Zakładzie Inżynierii Spajania Politechniki Warszawskiej, Biuletyn Automatyki 2/2011 (Astor).

[5] Cegielski P.: Rozdział 7.4 „Robotyzacja spawania” Technika spawalnicza w praktyce. Poradnik. Red. K. Ferenc. Warszawa, Verlag Dashofer 2017

[6] Cegielski P., Golański D., Kolasa A., Sarnowski T.: Modelowanie i wdrożenie wysięgników do lokomocji robotów przemysłowych, Przegląd Spawalnictwa 1/2015, s. 6-13.

[7] Cegielski P., Golański D., Kołodziejczak P., Kolasa A., Sarnowski T.: Studium rozwiązań konstrukcyjnych nowej generacji zewnętrznych osi robotów przemysłowych, Przegląd Spawalnictwa 11/2017, s. 84-92.
[8] Golański D., Cegielski P., Giżyński P., Kolasa A.: Modelowanie numeryczne ugięcia podstawy robotów przemysłowych, Przegląd Spawalnictwa 6/2014, s. 34-41.

[9] Honczarenko J.: Roboty przemysłowe, Budowa i zastosowanie, WNT Warszawa 2011.

[10] Katsich C., Badisch E.: Effect of carbide degradation in a Ni-based hardfacing under abrasive and combined impact/abrasive conditions, Surface \& Coatings Technology, 206, 2011, pp. 1062-1068.

[11] Kolasa A., Cegielski P.: Fully Automatic GMAW installation, 9th International Conference on Computer Technology in Welding, 28-30.09.1999, Detroit, Mich. USA.

[12] Paluch P.: Uniwersalne zrobotyzowane stanowiska spawalnicze, Praca dyplomowa magisterska, kierujący dr inż. P. Cegielski, 2016.

[13] Panas M.: Uproszczone programowanie off-line robotów Fanuc, Praca przejściowa inżynierska, kierujący dr inż. P. Cegielski, 2017. 